\title{
A dedication to Janet Mills
}

\section{1th May 1954-24th December 2007}

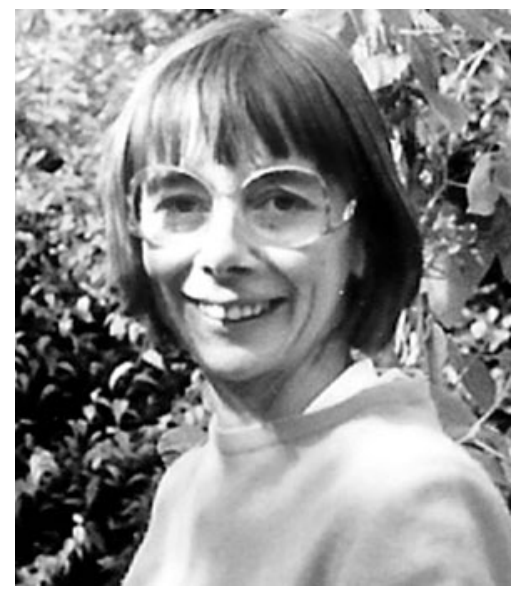

1972-75 University of York

(BA $1^{\text {st }}$ Class, music/maths)

1975-76 University of Leeds

(PGCE music/maths)

1976-79 Holy Family School, Keighley

(Head of Music, maths teacher)

1979-81 Brighouse Girls'Grammar School

(Head of Music, maths teacher)

1981-83 Oxford University

(D.Phil)

1983-88 Westminster College, Oxford

(Senior Lecturer, music and maths)

1988-90 Exeter University, School of Education

(Lecturer)

1990-2000 HM Inspector of Schools

(Specialist Advisor for Music 1995-2000)

2000-2007 Royal College of Music, London

(Research Fellow)

\section{Books}

Music in the Primary School (CUP 1991)

Music in the School (OUP 2005)

Instrumental Teaching (OUP 2007)

\section{Award}

National Teaching Fellowship, 2004 


\title{
Individual tributes from Janet's colleagues who reflect her various professional pathways and contributions
}

\author{
A tribute by Professor Clifford Madsen, Florida State University, College of Music, USA
}

My association with Janet Mills was as an international colleague as we interacted at ISME Research Commission meetings in many venues across the years. After several of these weeklong meetings one gets to know the "regulars" very well. Janet was a regular and I remember vividly the first time Janet attended this week-long seminar. It was readily apparent that this young woman obviously had the intellectual equipment to match anyone yet it was during the social or "play times" at these meetings that her personality came through. I remember her genuine sincerity, her attentive eye contact and her almost impish smile, which seemed always close to the surface, yet broke open from somewhere deep within. It was during the one to one times that she would answer any question and generously share her work with others. I have used many of her evaluative instruments in my own research, as have countless others. So with what does this short life leave us? Of course courage, determinism, and an indelible mark on the world music education community, yet more importantly a person one just cannot forget. Janet Mills was a unique individual and it would be almost impossible to describe her by any comparisons. As a scholar her body of work and penetrating analyses were always substantive and in many cases provided the models for others. Her ability to take enormously complex issues relating to music teaching and learning and categorize them was superior to anyone I know. Additionally, her absolute brilliance in devising evaluative instruments which measure these complex behaviors was both elegant in design and beautiful in transparent simplicity. Much more important for me is my highest accolade - Janet Mills was a very nice person.

\section{A tribute by Dr. Gordon Cox (past co-editor, BJME), University of Reading, UK}

When Stephanie Pitts and I became editors of BJME in 2003, we were delighted that Janet Mills agreed to serve on the Editorial Board. She had already formed a strong bond with the journal, from her first article which appeared in 1985 ('Gifted instrumentalists: how can we recognise them?') to others which derived from her work as one of Her Majesty's Inspectors of Schools (HMI) during the 1990s, including her observations about music technology, singing, and the transition between primary and secondary school. There was no doubt that Janet's sympathies lay with teachers, and she wanted to empower them to do as effective a job as possible. She was convinced that one way of achieving this effectiveness was by encouraging the idea of the teacher as researcher. This idea came to fruition within the context of the music conservatoire, in the special issue of $B J M E$ in 2005 'Instrumental Teaching in Higher Education' edited by herself and Hilary Moore. Significantly each of the articles was authored or co-authored by a performer-teacher, some of whom were new (education) researchers. It demonstrated her belief that educational research at its best, rather than being somehow arcane, stems from the unique perspectives, experience and understanding of practitioners. Similarly her own writing reflected her conviction put forward in Music in the School (2005), that educational research in music needed to be potentially useful with 'the capacity to improve the learners lot in music' 
(p. 213). Janet's influence upon music education in this country has been powerful and far-reaching, particularly in the raising of the standards of music teaching in schools. But she will especially be missed, by those of us fortunate enough to have known her, for those qualities which made her special, her humour, her straightforwardness, her warmth and her courage.

A tribute by Steve Tommey (Advanced Skills Music Teacher), Bishop Perowne Church of England College, Worcester, UK

"We all have potential as musicians". "Music is not a gift but a right". These words encapsulate Janet's belief and trust in everyone's musical capacity and shone through in everything she said, did and wrote. I first met Janet in the academic year 1994-1995. We had just introduced a course for specially auditioned young musicians and Janet had come to find out more. I remember vividly the moment I first saw her walking down a corridor looking me straight in the eye and introducing herself. The manner in which this was done was so approachable and friendly that it immediately put a quivering wreck on a more even keel. This didn't last long. Janet asked the first of her many highly considered questions and the quivering began again in earnest! Janet hardly ever gave me any direct answers, always questions, questions.... - thought provoking, soul searching and above all - eventually enlightening. She had an incredible way of knowing that her questions would lead people like me to new and exciting ways of understanding and developing my pedagogy. Janet's total support for young people and their entitlement to music education of the highest quality was one of her greatest qualities. Janet's accessibility and her faith in our abilities to deliver, became an inspiration to make it happen, which it did. Our partnership with the Royal College of Music is a unique one and continues successfully to this day thanks to Janet. It is said that no-one is indispensable. That's as maybe. But if we are talking irreplaceable, Janet is top of the class.

A tribute by Alan Dobson (former HMI for modern foreign languages), UK

I was privileged to know Janet for almost 20 years, most of them as HMI. In December we were still discussing educational issues. Janet was weak but intellectually alert and with her sense of humour intact. In debate with HMI, Janet could be very exacting. She shared the view that, if HMI cannot ask each other the hard questions, they are ill-prepared for their job. In schools, Janet maintained her rigour, but was always sensitive to local circumstances. I recall several headteachers who were left in no doubt about the issues but with their morale intact to face the challenge. On visit to a primary school, Janet was taken by the work of a particular teacher. A couple of weeks later she received a letter from the CEO. By chance, he had been in the school shortly afterwards. He wanted to thank her personally for the boost she had given that teacher. Inspiration should be celebrated, and in this case, it was. Janet still had much to offer as HMI when she felt she should move on. Free of the constraints of the $\mathrm{HMI}$ role, she was able to disseminate through speaking and writing the fruits of research and her insights into music education. She will be greatly missed. 
A tribute by Rosie Burt-Perkins (Royal College of Music (RCM) Research Officer)

Janet Mills was appointed Research Fellow at the Royal College of Music (RCM), London, in 2000. Already established as an inspirational and diverse music educator, Janet's aim was to open the door to the 'secret garden' of conservatoire education. Bringing together her research and teaching expertise, Janet founded and led the Music Education Research Team (MERT), working tirelessly to promote good practice both within the conservatoire and the wider music education community. A natural innovator, Janet quickly set about building new opportunities for RCM students and staff. Researching the careers of RCM alumni, Janet trained and employed a team of student researchers to conduct telephone interviews; working from the results of student focus groups and questionnaires, Janet established Learn to Teach, a voluntary 2-day course for aspiring instrumental teachers; in partnership with BJME in 2005, Janet co-edited a special issue on instrumental teaching in higher education, in which all of the articles were authored by performer-teachers. The list could go on and on, for Janet's contribution to conservatoire research and practice is immense. In demand as a writer and speaker, Janet disseminated her work widely, not least through the seminar series she founded at the RCM: she was passionate about bringing together teachers, students, researchers and policy makers for what she encouraged to be lively debate. Janet certainly achieved her aim of opening up the 'secret garden', leaving us all the better informed about music education both in the conservatoire and far beyond. Her legacy is sure to be long-lasting.

\section{A tribute by Professor Robert Walker, University of New South Wales, Sydney, Australia}

I first met Janet Mills at an international research seminar in Victoria, Canada, in 1984 where she read a fascinating paper on aspects of music performance in children. Over the next quarter of a century her research has become internationally known and recognized as among the most important contributions in the field. As a regular invited contributor to the Research Seminars of the International Society for Music Education over the last 20 years she made many friends and gained many admirers of her research. Such was her impact on the world of research in music education that she has been invited to give keynote speeches on every continent. Janet will be sorely missed by the international research community, not least for her level-headed approach to complex issues, her humour, her humanity and gentleness in dealing with young, inexperienced, researchers, and her wisdom in articulating with great common sense important basic issues in the extremely complex matter of studying and understanding music acquisition among the young. We are the richer for having known her, and sharing with her the enthusiasm and highly expert skills she brought to her research. But Janet was also a keen gardener who, on one of her visits to my home in Canada, spent half a day setting seeds in a barren part of my garden. The mature plants are still there, as are the results of the seeds she sowed through her research among many across the world who met her and her work. 